\title{
What is OR?
}

The desirability of a succinct, 'one-page' description of $O R$ in practice has been recognized for some time by operational researchers. MICHEL JOHNSON volunteers the following description - which could be used by the Society in its publicity material.

Operational research (OR) practitioners are employed In a wide variety of organlzations, in areas whlch include central and local government, the milltary, commerclal and manufacturing operatlons and community development inltiatives. Within organizations, help can be provided in an extenslve range of functions - for example: finance; personnel; distributlon; productlon; supply; sales and marketing.

Operational research work is of substantlal value to managers and it provldes considerable excitement and challenge for practltloners. In co-operatlon with those responslble for the allocatlon of resources, OR staff help to find new approaches to problems and, generally, help to promote beneflcial change. A summary (offered by Professor Russ Ackoff) of the process of OR work Is that, working with others, it involves "designing a desirable future and inventing ways of bringing it about".

A great deal of OR work is concerned with structuring 'messy' problems - analyzing systems, identifying objectives, resolving priorities, visualizlng opportunitles, definlng alternative courses of actlon, estimating costs and benefits, and so on (Report of the Commission on the Future Practice of $O R, 1986)$. Thls gives considerable scope for the exerclse of Ingenuity. The work has stlmulating and rewarding Intellectual content as well as requlring practitioners to exhlbit substantlal skills in teamwork, consultation, communlcation and persuasion.

It is equally important for OR staff to have up-to-date expertise In effective business and commerclal practlce. This will cover areas such as offlce procedures, information technology, stock control, quality control, performance monitoring, planning and scheduling techniques, accounting, budgeting, forecasting, financial reporting and personnel administration. To this end, a range of courses is provided by universities, polytechnics, consultancy organizations and the OR Soclety itself. The meetings and conferences organized by the Society are also important for the dissemination of knowledge and understanding.
The process of dolng OR work over recent decades has given rise to a 'modelling' technology which can be of substantial value in promoting new thinklng and in analyzing the structure of problems. Essentially, this is a quantitative and exploratory technology, based on Ideallzations of real-world problems and Involving 'sampling' and 'sImulation' calculations. Typlcally, the technology relates to such problem characterlstics as uncertalnty In forecasting, constralnts of space and time, varlations about averages, differences between plans and actuals, apparently Irreconcllable criterla of performance and seemingly Irratlonal and confllcting behavlour patterns.

It is by familiarity with these techniques, training and interactlon with colleagues at meetings and conferences that the OR practlitioner can offer a constructive and often original viewpoint In the solutlon of management problems. Freed from the responslbilitles of day-to-day operatlonal management, OR practitioners are often in a position to use imagination, but they must expect to share in the responsibility for actions based on thelr advlce. In particular, OR staff can expect to be Involved not only In the design and Implementation stages of a project, but also in the subsequent updating and enhancement of procedures. In thls context, the need to carry responslbility may be considerable.

Depending on the organization and location of the OR group, OR practltioners may speciallze In developments In Information technology. Many become Involved in more general business consultancy and many others become managers of actlvitles concerned with the planning and co-ordinatlon of the use of resources. Qulte a few progress to hlgh positlons of responslbility in the management hlerarchy.

\section{Reference}

Report of the Commission on the Future Practice of Operational Research (1986), J. Opl Res. Soc. Vol. 37, No. 9.

MICHEL JOHNSON has been involved with operational research since the mid-1950s and has worked at United Steel, Courtaulds and Rowntree, gaining extensive management experience over a wide range of management service activities. He was a founder member of the Yorkshire and Humberside OR Group, a member of the ORS Council in the early 1970s and Chairman of the 1978 Conference Committee. He joined the Education and Research Committee soon afterwards, and was Vice-President of the Society from 1985 until 1987.

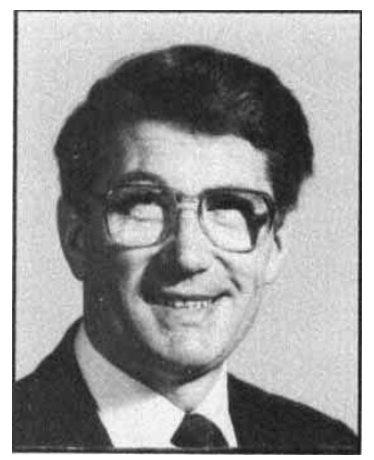

Views and comments on this article are particularly welcome. Please write to the Editor. 